\title{
Bench-scale Overproduction and Purification of recombinant GCSF in Escherichia coli fed-batch process
}

\author{
Valiollah Babaeipour ${ }^{*}$, Mohammad Reza Mofid, Sirwan Khanchezar, Faezeh Faraji, Somayeh Abolghasemi \\ Malek Ashtar University of Technology, Isfahan University of Medical Sciences, Tarbiat Modares University, Islamic Azad University
}

\begin{tabular}{|c|c|}
\hline ARTICLE INFO & ABSTRACT \\
\hline Article history: & \multirow{5}{*}{$\begin{array}{l}\text { Fermentation process scale up can change the hydrodynamic conditions of recombinant } E \text {. coli cultivation } \\
\text { bioreactor and reduce productivity in the same operating conditions that have been developed at lab scale. In this } \\
\text { study, an efficient strategy was used to scale up recombinant human GCSF production in the fed-batch culture } \\
\text { of } E \text {. coli. Heterologous production of human GCSF was done in the fed-batch culture of Escherichia coli BL21 } \\
\text { (DE3) with feeding strategy of maximum attainable specific growth rate. Then, fed-batch process was scaled up } \\
\text { based on geometrical analogy and constant DO. Rh-GCSF was overexpressed as inclusion body (IB). Then IBs } \\
\text { were released by cell disruption afterward solubilized and refolded properly. Eventually, cation exchanger } \\
\text { chromatography was applied for the rh-GCSF purification. By induction at cell density of } 75 \mathrm{~g} \text { dry cell weight } \\
\text { per } 1 \text { (g dcw/l), final cell density and rh-GCSF concentration in both scales were } 124 \text { and } 114 \mathrm{~g} \text { dcw/l, and } 22 \\
\text { and } 19 \mathrm{~g} \text { protein/l obtained, respectively. Recovery yield of purification process was } 400 \mathrm{mg} \text { purified gcsf per } 1 \\
\mathrm{~g} \mathrm{IB} \text { and recombinant protein purity was greater than } 99 \% \text {. Insignificant decrease of the biomass and rh-GCSF } \\
\text { production (less than } 10 \text { percent) during scale up indicates efficiency of scale up method. }\end{array}$} \\
\hline Received on: $12 / 01 / 2017$ & \\
\hline Accepted on: $27 / 05 / 2017$ & \\
\hline Available online: $30 / 08 / 2017$ & \\
\hline $\begin{array}{l}\text { Key words: } \\
\text { rh-GCSF, Fed-Batch, } \\
\text { Geometrical Analogy, } \\
\text { Overproduction, Purification, } \\
\text { Escherichia coli. }\end{array}$ & \\
\hline
\end{tabular}

\section{INTRODUCTION}

Granulocyte-colony stimulating factor of human (hGCSF) is a single chain protein (MW=18.8 $\mathrm{kDa}$ ) made up of 174 amino acid residues (Babaeipour et al., 2010). GCSF is a growth factor which motivates proliferation and differentiation haematopoietic precursors of neutrophil granulocytes, and to boost the production of white blood cells in the bone marrow. Active GCSF encompasses two intramolecular disulfide bonds and a free cysteine at position 17 (Babaeipour et al., 2015). Fermentation of microorganism is an important process in the industrial biotechnology branch which is used for production of biomass, proteins and other biomaterials. Volumetric productivity enhancement of recombinant microorganisms fermentation process usually is achieved in high cell density and more specific productivity (amount of production per cell) that can be obtained through fed-batch cultivation

\footnotetext{
* Corresponding Author

Email: vbabaeipour @ mut.ac.ir
}

(Matsui et al., 2006; Chung et al., 2006). Hence, to achieve a successful high cell density culture (HCDC), selection of nutrient feeding strategy is critical issue (Tripathi, 2009; Choi, 2006). The exponential feeding strategy lets cells grow at a specific growth rate (Tripathi, 2009; Choi, 2006; Thiry and Cingolani., 2002) and adjust glucose concentration near zero without fluctuation thus causes minimum perturbation on cellular carbon metabolism (Choi, 2006). HCDC has several drawbacks too, including limited availability of dissolved oxygen, acetate formation and reduced mixing efficiency which amplified by scale-up (Choi, 2006; Thiry et al., 2002). Developing of proper HCDC conditions requires in the fermentation scale up, because of heat and mass transfer problems which arise in the large scale bioreactors (Thiry et al., 2002; Hewitt et al., 2000). Generally, scale up ratio is 1:10, however lower ratios of about 1:5 often result in enhancing comfort level (Junker, 2004). Scale-up of bioreactors is performed with different strategies such as geometrical analogy, power input per unit volume, mixing time and oxygen transfer. Based on geometrical analogy, bioreactors with a standard geometry are beneficial to scale up. 
In the fed-batch culture of $E$. coli, dissolved oxygen often becomes rare owing to its little solubility ( $7 \mathrm{mg} / \mathrm{l}$ in water) (Matsui et al., 2006), therefore minimum acceptable value of DO in medium is suitable criteria to scale up which usually known from laboratory studies. DO above lower limit of $10-30 \%$ saturation oxygen concentration can be adequate (Junker, 2004).

In this research, fed-batch fermentation of recombinant E. coli producing GCSF was scaled up based on simultaneously maintaining geometrical analogy and DO in appropriate limit of 10-30\% saturation. Also, effect of scale-up on the cell growth and the recombinant GCSF production kinetics was evaluated.

\section{MATERIALS AND METHODS \\ Host and expression vector}

E. coli BL21 (DE3) (Novagen, Inc.) was applied as the host for expression of rh-GCSF. The inducible expression vector of pET23a (Novagen, Inc.) which carries the rh-GCSF gene was placed into the NotI and NdeI sites (Jafari et al., 2014). To obtain recombinant $E$. coli strains, expression vectors were transformed into host cells by using the calcium chloride manner.

\section{Media and solutions}

The modified M9 medium contains $1 \%(\mathrm{w} / \mathrm{v})$ glucose, $\mathrm{KH}_{2} \mathrm{PO}_{4} 7.5 \mathrm{~g} / \mathrm{l} ; \mathrm{K}_{2} \mathrm{HPO}_{4} 15 \mathrm{~g} / \mathrm{l}$; citric acid $2 \mathrm{~g} / \mathrm{l} ;\left(\mathrm{NH}_{4}\right)_{2} \mathrm{SO}_{4} 2.5 \mathrm{~g} / \mathrm{l}$; $\mathrm{MgSO}_{4} \cdot 7 \mathrm{H}_{2} \mathrm{O} 2 \mathrm{~g} / \mathrm{l}$ and $1 \mathrm{ml}$ solution of trace element per 1 was used as seed culture and fermentation medium. The solution of trace element contains 2.8 g CoSO $_{4} .7 \mathrm{H}_{2} \mathrm{O} ; 2.8$ g FeSO$_{4} .7 \mathrm{H}_{2} \mathrm{O} ; 1.5$ g CaCl $2.2 \mathrm{H}_{2} \mathrm{O} ; 2 \mathrm{~g} \mathrm{MnCl}_{2} .4 \mathrm{H}_{2} \mathrm{O} ; 0.2 \mathrm{~g} \mathrm{CuCl}_{2} .2 \mathrm{H}_{2} \mathrm{O}$; and $0.3 \mathrm{~g}$ $\mathrm{ZnSO}_{4} .7 \mathrm{H}_{2} \mathrm{O}$ for each 1 in $1 \mathrm{M} \mathrm{HCl}$ solution. Ampicillin (100 $\mathrm{mg} / \mathrm{ml}$ ) was added to all cultivation media.

\section{Fed-batch cultivation}

HCDC was performed by using fed-batch fermentation. The fed-batch culture was performed in this way: at first the cells were cultivated in a batch step to stabilize cells and achieve proper cell density. After carbon source depletion, the cells were fed exponentially with a predetermined feeding rate. Rate of feeding was enhanced stepwise according to the exponential feeding strategy with highest achievable specific growth rate (lower than critical value). The medium which was used as feed contained glucose $(700 \mathrm{~g} / \mathrm{l}), \mathrm{MgSO}_{4}(20 \mathrm{~g} / \mathrm{l})$ and trace elements solution (5 $\mathrm{ml} / \mathrm{l})$. The solution of $25 \%(\mathrm{w} / \mathrm{v}) \mathrm{NH}_{4} \mathrm{OH}$ was used for sustaining $\mathrm{pH}$ at 7 and providing the required nitrogen source. The amount of phosphate added at the start of fed-batch culture is enough by the end of the process. The temperature was maintained at $37{ }^{\circ} \mathrm{C}$ and IPTG was used as inducer. The exponential feeding rate determined by the following equation (Lee, 1996):

$$
F(t) . S(t)=\left[\mu / Y_{x / s}+m\right] X_{t o} \cdot V_{t o} \exp \left[\mu \cdot\left(t-t_{0}\right)\right]
$$

where $\mathrm{V}$ is the volume of culture in the bioreactor, $\mu$ specific growth rate coefficient $\left(\mathrm{h}^{-1}\right), \mathrm{S}$ substrate concentration, $\mathrm{F}$ volumetric feeding rate $(\mathrm{ml} / \mathrm{min}), \mathrm{t}$ the time $(\mathrm{h}), \mathrm{m}$ specific maintenance coefficient and $\mathrm{Y}_{\mathrm{x} / \mathrm{s}}$ coefficient yield of biomass per substrate (g DCW/g glucose). Furthermore, $\mathrm{t}_{0}(\mathrm{~h}), \mathrm{V}_{\mathrm{t} 0}(\mathrm{l})$ and $\mathrm{X}_{\mathrm{to}}(\mathrm{g}$ $\mathrm{dcw} / \mathrm{l})$ are the feeding starting time, volume of culture and cell concentration at the start of each feeding step, respectively. Feeding rate was determined versus time by assumptions $\mathrm{X}_{\mathrm{t} 0}=5$ $\mathrm{g} / \mathrm{l}, \mu=0.4 \mathrm{~h}^{-1}, \mathrm{~m}=0.02, \mathrm{Y}_{\mathrm{x} / \mathrm{s}}=0.5 \mathrm{~g} / \mathrm{g}$ and $\mathrm{t}_{0}=0$. The concentrations of glucose and acetate were monitored manually at $10 \mathrm{~min}$ periods. By assumptions that carbon source accumulation during feeding stage is zero (quasi steady state for carbon source), constant volume of culture (use of concentrated feed, $700 \mathrm{~g} / \mathrm{l}$ ) and constant specific growth rate coefficient (exponentially feeding rate) for each feeding step, the feeding rate is determined versus time.

\section{Scale up approach}

Fermentation scale up has been done based on geometrical analogy and constant DO. Standard bioreactor vessels with constant geometry were used for scale up procedure. Volumes of bioreactors used were 2 and 131 with 1 and 81 working volume, respectively. Maintaining DO above lower limit of $20 \%$ was achieved by increasing the air flow rate, increasing the stirrer speed and using enriched air with oxygen (Junker, 2004).

\section{Analytical method}

Growth of cells was checked by determining dry weight of cell and optical density (OD) of culture at $600 \mathrm{~nm}$. Glucose was examined by using enzymatic kits (ChemEnzyme CO., I.R. Iran). Acetic acid concentration was determined by using Boehringer Mannheim Kit 148261.

The stability of plasmid was specified by cultivation samples from fermented media on LB agar plates with and without ampicillin. Afterward, the ratio of plasmid containing cells on LB media with ampicillin to those in LB without antibiotics was computed as stability of plasmid (Babaeipour et al., 2007).

The amount of rh-GCSF expression was specified by using SDS-polyacrylamide gel electrophoresis with $12.5 \%(\mathrm{w} / \mathrm{v})$ acrylamide [Weber et al., 1972]. Gels were marked with Coomassie brilliant blue R250, and then computed by gel densitometer. The total amount of protein was determined by Bradford method [Bradford, 1976]. Differentiated proteins on the SDS-PAGE gels were transferred and spotted on the PVDF membrane for identifying the exact existence of rh-GCSF [Burnette, 1986]. PVDF sheet was clogged with 3\% BSA in TBST solution ( $\mathrm{pH} 7.5,20 \mathrm{mM}$ Tris- $\mathrm{HCl}, 150 \mathrm{~mm} \mathrm{NaCl}$, and $0.05 \%$ Tween 20). At that time, anti-GCSF polyclonal antibody at a dilution of 1:500 in TBS-T solution was added for $1 \mathrm{~h}$. with HRP anti-rabbit (1:1000) in TBS-T a subsequent incubation was performed and with Diaminobenzine (DAB) solution $(0.5 \mathrm{mg} / \mathrm{ml}$ DAB, $0.1 \% \mathrm{H}_{2} \mathrm{O}_{2}$ ) the third incubation of 5-10 min was carried out. At the end of fermentation processes, some samples were gathered for more purification and analysis by recently established approach (Abolghasemi et al., 2010).

\section{Purification of rh-GCSF}

Cell disruption and IB recovery: The fermented media was centrifuged at $8000 \mathrm{~g}$ and $4{ }^{\circ} \mathrm{C}$ for $30 \mathrm{~min}$ and with $50 \mathrm{mM}$ 
phosphate buffer $\mathrm{pH} 7.4$ the acquired pellet was washed two times. $50 \mathrm{~g}$ of these wet cells were dispersed in $200 \mathrm{ml}$ of lysis buffer. The lysis buffer is composed of $50 \mathrm{mM}$ Tris- $\mathrm{HCl}$ comprising 1 $\mathrm{mM}$ PMSF and $1 \mathrm{mM}$ EDTA. Cell lysis were done by passing through a high pressure homogenizer thrice (NIROSOAVI) at 800 bars. Between each pass the gained suspension was chilled to $4{ }^{\circ} \mathrm{C}$. The IBs was harvested by centrifugation the cell lysate for $30 \mathrm{~min}$ at $6000 \mathrm{~g}$ and $4^{\circ} \mathrm{C}$ and the supernatant thrown away.

Washing of IBs: The obtained IBs pellet in preceding stage was suspended in the initial washing buffer $(50 \mathrm{mM}$ Tris$\mathrm{HCl} ; 2.5 \mathrm{~g} / \mathrm{l}$ Triton X-100; $1 \mathrm{mM}$ PMSF and 5 mM EDTA (pH=8)) and incubated for $40 \mathrm{~min}$, then by centrifugation at $8000 \mathrm{~g}$ and 4 ${ }^{\circ} \mathrm{C}$ for $30 \mathrm{~min}$ were harvested. In the second washing step, $350 \mathrm{mg}$ washed inclusion body pellets was dispersed in the wash buffer 2 (containing $2 \mathrm{M}$ urea) and incubated for the duration of 40 minutes and then harvested by centrifugation for $30 \mathrm{~min}$ at $4{ }^{\circ} \mathrm{C}$ and $8000 \mathrm{~g}$.

IBs solubilization and refolding: At that moment, $350 \mathrm{mg}$ of the washed IBs was solubilized in $10 \mathrm{ml}$ IB dissolving buffer (8 M Urea; 1mM EDTA; $100 \mathrm{mM} \mathrm{GSH} ; 30 \mathrm{mM}$ Tris- $\mathrm{HCl}$ with $\mathrm{pH}$ 12). The solubilized IBs was kept warm at $25-28{ }^{\circ} \mathrm{C}$ for $45 \mathrm{~min}$ and centrifuged at $10000 \mathrm{~g}$ for $30 \mathrm{~min}$ to throw out insoluble cell fragments. $350 \mathrm{mg}$ of the dissolved inclusion bodies was refolded by $10 \mathrm{ml}$ refolding buffer and incubated for $12 \mathrm{~h}$ at $4^{\circ} \mathrm{C}$ then for 20 $\min$ at $10,000 \mathrm{~g}$ and $4^{\circ} \mathrm{C}$ were centrifuged. Composition of refolding buffer is $3 \mathrm{M}$ Urea at $\mathrm{pH}=5 ; 30 \mathrm{mM}$ Tris $-\mathrm{HCl} ; 2 \mathrm{mM}$ GSSG; $1 \mathrm{mM}$ EDTA and $20 \mathrm{mM} \mathrm{GSH}$.

Cation exchanger column: By adding $2 \mathrm{M}$ Acetic acid the $\mathrm{pH}$ of renatured protein was set to 5 then transferred into mono $\mathrm{Q}$ column in FPLC (SYKAM-S2100). Flow rate and temperature of the column were sustained at $1 \mathrm{ml} / \mathrm{min}$ and $20{ }^{\circ} \mathrm{C}$ respectively all over the process. By using 3 bed volumes of $25 \mathrm{mM}$ sodium acetate buffer $(\mathrm{pH}=5)$, the mono $\mathrm{Q}$ column was equilibrated. The refolded protein sample was directly loaded onto the column at the same flow rate. Finally by using 3 bed volumes of the same buffer with $1 \mathrm{M} \mathrm{NaCl}$, the used column was washed thoroughly.

\section{RESULTS}

Figure (1) was illustrated the effect of scale up on specific growth rate in fed-batch cultivation of bacteria. As depicted (figure 1), specific growth rate was changed approximately same in both scales and decreased slightly due to scale up. At the first stage of the process, the specific growth rate was high by depletion of carbon source and starting the feeding, specific growth rate was controlled under critical value (less than $0.5 \mathrm{~h}^{-1}$ ) to prevent acetate production. In the next chart (figure 2(a)), it was illustrated that due to decrease in the specific growth rate in upper scale, feeding rate and cell density reduced and consequently process time increased $(1 \mathrm{~h})$. This little decrease in specific growth rate and feeding rate has not considerable influence on the final cell density (less than 10\%). Final cell densities in 1 and 81 bioreactors were 124 and $114 \mathrm{~g} \mathrm{DCW/l,}$ respectively.

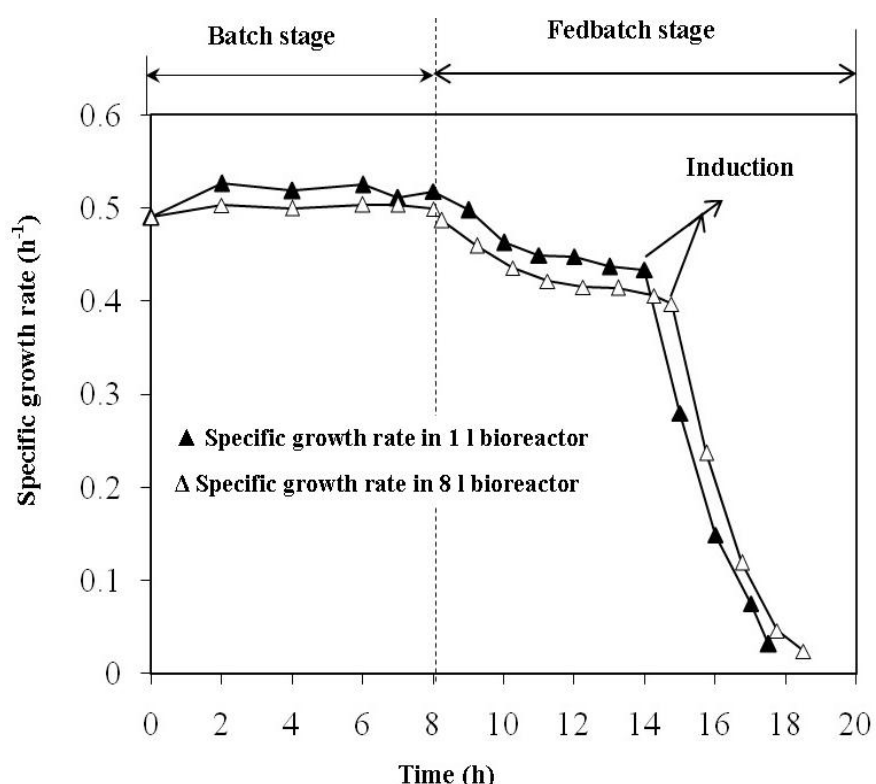

Fig. 1: Effect of fed-batch cultivation scale-up on specific growth rate of $E$. coli BL21 (DE3) [pET23agcsf]. $(\mathbf{\Delta}),(\Delta)$ Specific growth rate in 1 and 81 volumes, respectively.

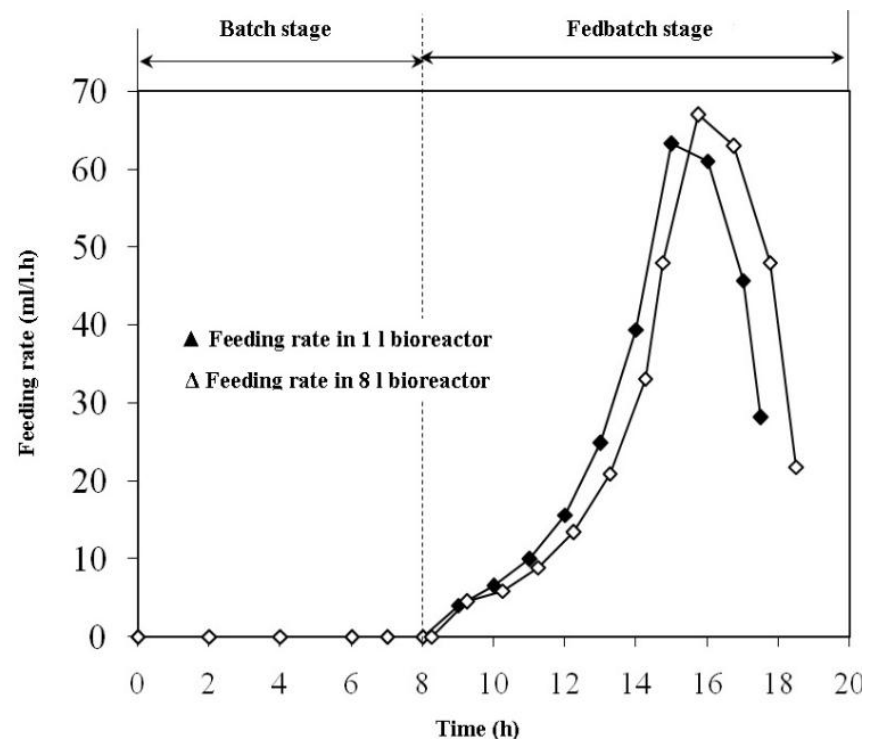

Fig. 2: Effect of scale-up on feeding rate in fed-batch cultivation of $E$. coli BL21 (DE3) [pET23agcsf]. $(\boldsymbol{\Lambda}),(\Delta)$ Feeding rate in 1 and 81 volumes, respectively.

An essential prerequisite to achieve high production yield of recombinant protein especially in large scale process is plasmid stability [12]. Figure 3(a) shows the plasmid stability of pET23a+ [rh-GCSF] during scale up. Plasmid stability at the end of the process decreased from $95 \%$ to $90 \%$ for small and large scale, respectively. Since specific growth rate decreased due to scale up, plasmid stability in large scale was lower than small one. Figure 3(b) shows the effect of fed-batch scale up on production of rhGCSF. Due to scale up, production of rh-GCSF reduced from 22 to $19 \mathrm{~g} / \mathrm{l}$ and recombinant protein production efficiency also 
decreased from 182 to $174 \mathrm{mg}$ of recombinant protein per dry cell weight, respectively.

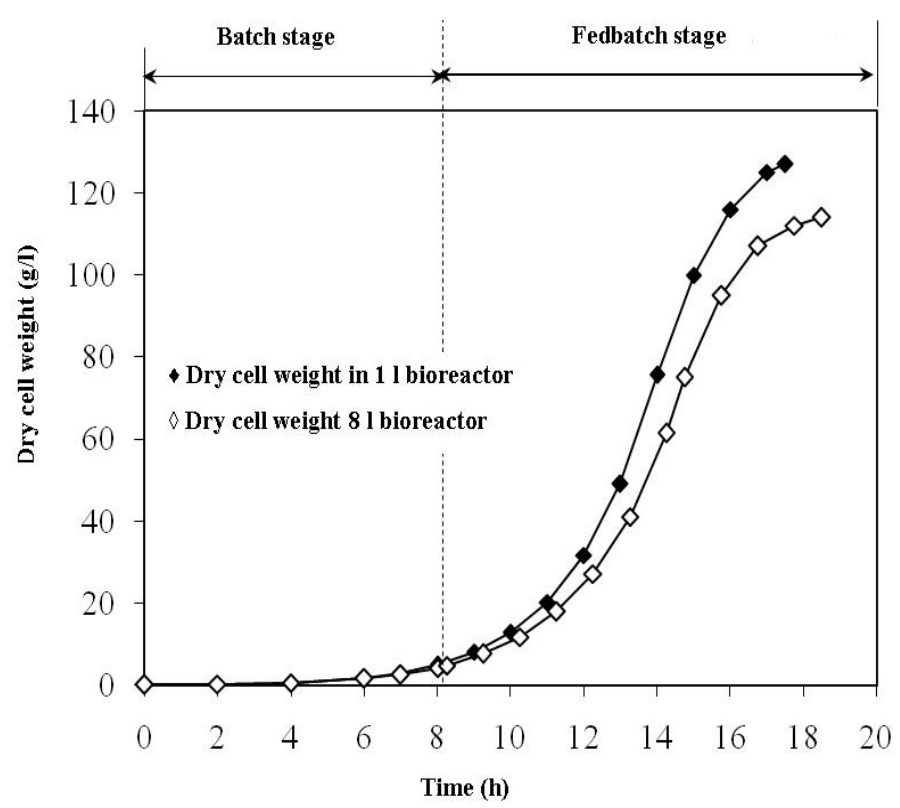

Fig. 3a: Effect of fed-batch cultivation scale-up on DCW of E. coli BL21 (DE3) [pET23a-gcsf]. ( $\bullet),(\diamond)$ DCW of culture in 1 and 81 volumes, respectively.

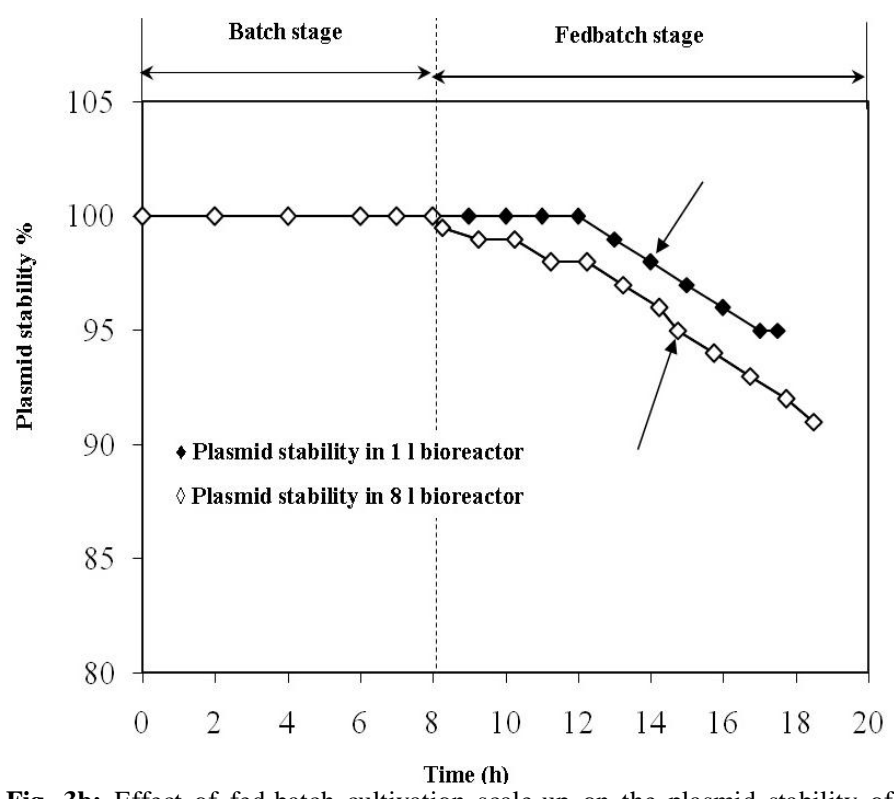

Fig. 3b: Effect of fed-batch cultivation scale-up on the plasmid stability of recombinant E. coli BL21 (DE3) [pET23a-gcsf] (\%). ( $\diamond),(\diamond)$ Plasmid stability in 1 and 81 bioreactors, respectively. Vectors show induction time.

Figure 4 indicates the effect of scale-up on the glucose and acetate concentrations in the culture. Changes in the concentration of glucose and acetate in the both scales are approximately the same. By starting the feeding then increasing cell density and consequently increasing heterogeneous conditions (which is amplified with scaling up), changes in glucose and acetate concentrations didn't follow the same pattern in both scales but their concentration were less than inhibitory level.

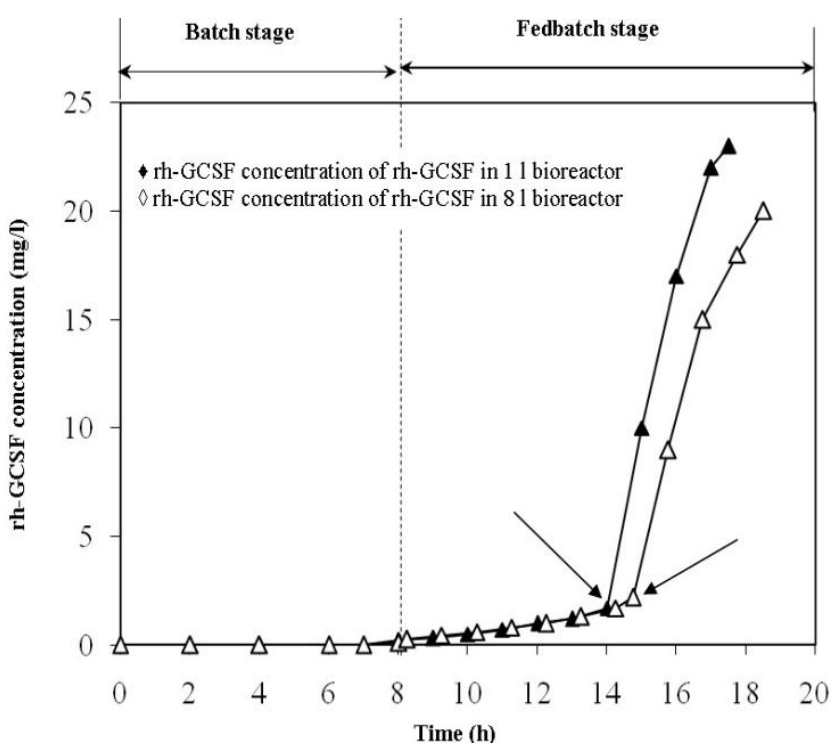

Fig. 4: Effect of fed-batch cultivation scale-up on rh-GCSF production $(\mathrm{g} / \mathrm{l})$ in E. coli BL21 (DE3) [pET23a-gcsf]. ( $\bullet),(\diamond)$ rh-GCSF concentration in 1 and 81 bioreactors, respectively. Vectors show induction time.

The SDS-PAGE gel (12.5\% acrylamide) of total cell proteins expression of $E$. coli BL21 (DE3) [pET23a-gcsf] and Western blot of rh-GCSF expressed in E. coli BL21 (DE3) are shown in figure (5), respectively. Computable analysis of the SDSPAGE gel of harvested samples by gel densitometer indicates that the amount of expression of rh-GCSF is about $35 \%$.

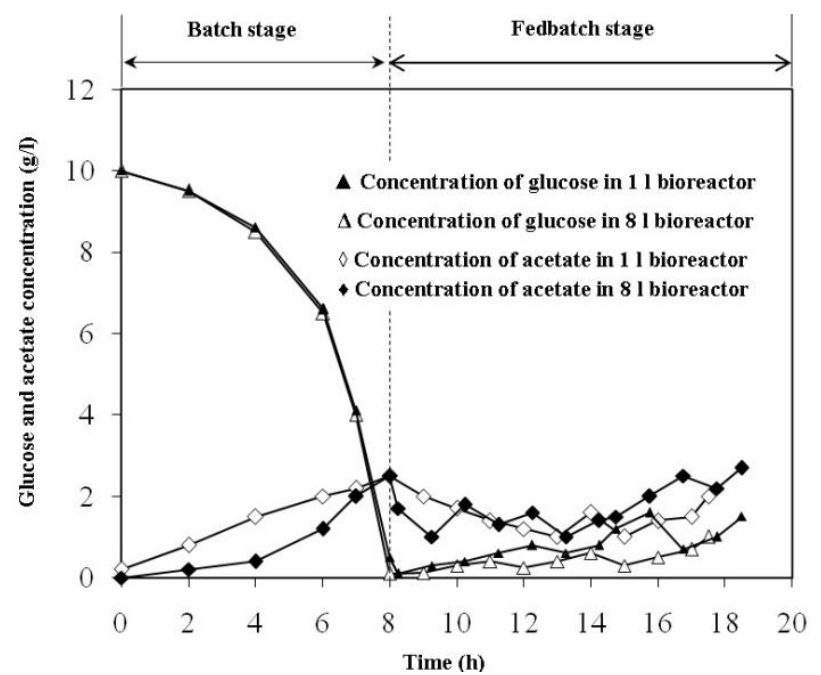

Fig. 5: Effect of scale up of fed batch cultivation of E. coli BL21 (DE3) [pET23a-gcsf] on glucose and acetate concentration. $(\boldsymbol{\Delta}),(\Delta)$ glucose concentration in 1 and 81 bioreactors, respectively. $(\diamond)$, ( $\bullet$ Acetate concentration in 1 and 81 bioreactors, respectively.

The quantifiable analysis by Bradford indicates that yield of the purified rh-GCSF is $400 \mathrm{mg}$ for each $1 \mathrm{~g}$ IB protein $(40 \%)$. The analysis of the purified rh-GCSF by SDS-PAGE (gel densitometry) and SEC displays that the purity is over than $99 \%$. Furthermore two stage washing method is enough to remove DNA 
of host cell and proteins (data not shown). In according to the presented results in this study, it can be understood that the purified rh-GCSF protein is highly pure and analogous with the innovator products as PDgrastim and Neupogen ${ }^{\circledR}$.

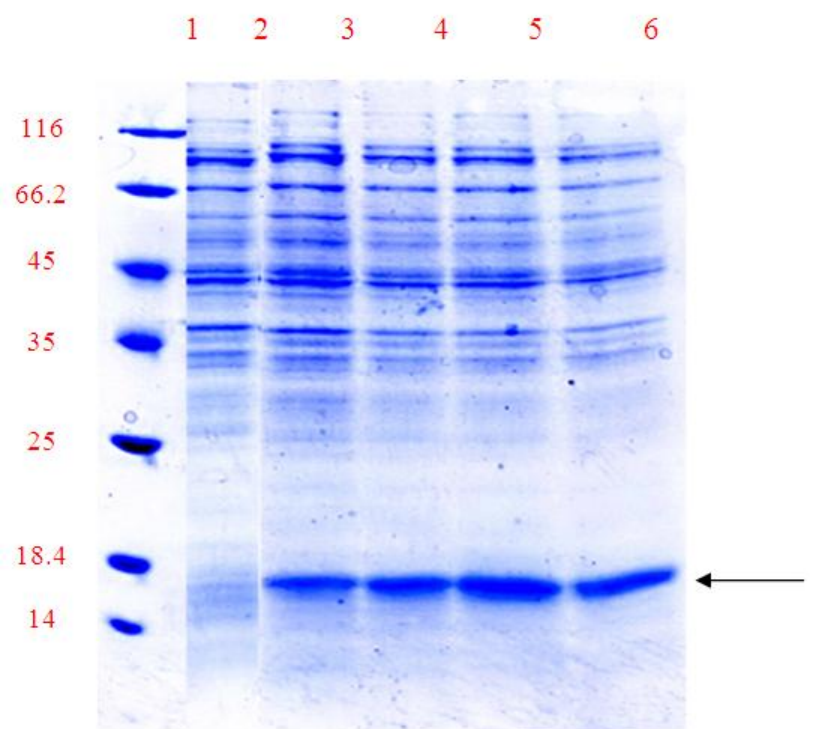

Fig. 7: SDS-PAGE gel (12.5\% acrylic amide) of rh-GCSF expression in fedbatch culture for $E$. coli BL21 (DE3) [pET23a-gcsf]. lane1: Molecular weight marker, lane 2: induction time, lane 3, 4, 5 and 6: 1, 2, 4 and $3 \mathrm{~h}$ after induction, respectively.

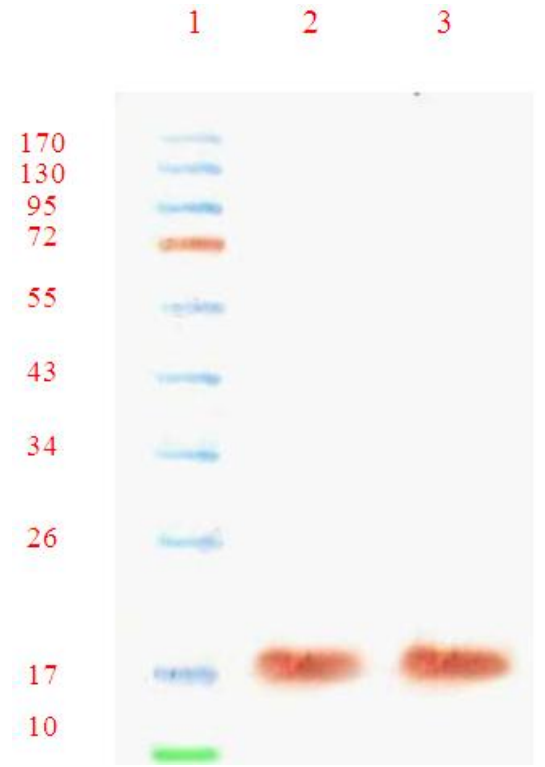

Fig. 8: Western blot analysis of rh-GCSF expressed in E. coli BL21 (DE3). Lane 1: molecular weight marker (\#SM0671, Fermentas), lane-2: rh-GCSF expression $4 \mathrm{~h}$ after induction, lane-3: reference standard (Neupogen $\left.{ }^{\circledR}\right)$.

\section{DISCUSSION}

Decrease of specific growth rate in the larger bioreactor was a result of heterogeneous condition occurred by scale up. Heterogeneous condition led to restriction in oxygen and carbon sources which reduced the specific growth rate of bacteria (Ge et $a l .$, 2005). During feeding stage of the process, the increase in the cell concentration restricted the oxygen mass transfer (decline of DO) and caused sharp change in the hydrodynamic conditions. Therefore, feeding rate (figure 2(a)) and specific growth rate decreased. After induction, specific growth rate diminished sharply due to metabolic load of recombinant protein overproduction, therefore the feeding rate decreased too. Owing to sever change in hydrodynamic condition in larger scale bioreactor decrease in the specific growth rate of bacteria in feeding stage was more than small one. But insignificant decrease in the biomass production (less than 10 percents) after fed-batch fermentation scale-up indicates efficiency of applied method.

Plasmid stability is correlated with copy number plasmids, size of inserted DNA and culture conditions such as temperature, composition of the media and the growth rate. Generally it is observed that plasmid stability enhances with increasing the specific growth rate (Valentinotti el al., 2003: Babaeipour et al., 2007), because in higher growth rate difference between specific growth rate of bacteria without plasmid and with plasmid is low. Then with decrease in the specific growth rate, this difference increases and consequently number of bacteria without plasmid rapidly increases in a short time. In this study specific growth rate in larger bioreactor was less than small one therefore; plasmid stability decreased due to scale-up. Then by choosing exponential feeding strategy with highest attainable specific growth rate, plasmid stability can be maintained in a high level (Babaeipour et al., 2013). Plasmid loss occurs significantly over the post-exponential growth phase during protein expression period (figure 3(a)). Decrease in the plasmid stability after induction in both scales was owing to increased metabolic pressure resulting from over-expression of recombinant protein and therefore decrease of specific growth rate (Lee, 2006: Babaeipour et al., 2007) thus antibiotic was used while induction of the process.

As depicted in the previous section, the efficiency of scale-up method was because of the higher specific growth rate during the process that can enhance production of recombinant protein, probably through higher ribosome content (Babaeipour et al., 2007 and 2013, Varedi et al., 2006) and high plasmid stability. Reduce in the biomass production because of the decrease in specific growth rate was less than $10 \%$. So decrease in the final cell density (figure 2(b)) and plasmid stability (figure 3(a)) decreased the amount of recombinant protein production (figure 3(b)) and eventually had a negative effect on the efficiency of recombinant protein production. But decrease in these factors was low therefore had a little effect on the recombinant protein production yield (less than 13\%). Also low level of the oxygen supply (20\% DO) used for fed-batch cultivation of $E$. coli was sufficient for sustaining plasmid in stable method and to acquire fairly high specific yield of rh-GCSF production (Phue and Shiloach, 2005).

High acetate concentration in the culture can inhibit growth of recombinant $E$. coli and reduce recombinant protein production (Thiry and Cingolani, 2002). When E. coli is grown under oxygen-limited or anaerobic conditions, acetate is 
manufactured as main by-product (Babaeipour et al., 2013). Type of $E$. coli strain influences on acetate production in aerobic fermentation processes (Phue and Shiloach, 2005; Rao et al., 2008) and take places when growth rate on glucose is high, (Phue and Shiloach, 2005; Shiloach and Fass, 2005) oxygen concentration is low (Phue and Shiloach, 2005; Bylund et al, 1998) and glucose concentration is excess (Phue and Shiloach, 2005; Bylund et al, 1998; Thiry and Cingolani, 2002). Then heterogeneous condition due to scale up makes points with excess glucose and low oxygen concentration (Bylund et al, 1998), thereby acetate production is increased in larger bioreactor.

It is considerable that acetate concentration at both scales is less than $3 \mathrm{~g} / \mathrm{l}$ and has no significant inhibitory effect on bacterial growth or protein production. In the early stage of fedbatch cultures that cell density is rather low; acetate production can be restricted by controlling feeding rate of the glucose as main carbon source. As cells grow, the rate of feeding must be increased without production of acetate.

Thus the main problem is to retain a high feeding rate whereas preventing excess metabolism and avoiding anaerobic situations (Akesson et al., 2001). During gene expression period, the growth rate decreased therefore to avoid acetate production, feeding rate are decreased too. By maximum attainable specific growth rate less than inhibitory level, supplying glucose slowly (Trinh et al., 2003) and widely used E. coli BL21 (DE3) as a host (which is lower acetate producer), acetate accumulation was decreased significantly. However during the fermentation process especially after induction, acetate concentration changes do not follow same pattern in both scales (figure 4). It is because of heterogeneous conditions in the large scale that intensify by increase in cell concentration.

Results scale-up of batch and fed-batch fermentation of a wild E. coli of bioreactor 1 to 10 and 100-liter on the basis of geometric analogy and ratio impeller power consumption per volume $(\mathrm{P} / \mathrm{V})$ has shown that scale-up don't have a significant impact on the final cell density (Li B, Sha M, 2016). Of course these result may change for recombinant $E$. coli that is more sensitive due to the resulting tensions plasmids heterologous. On the other hand the reported final cell density is less than half of existence research. In other research that scale-up was done basis on maintaining DO, it has been reported of the final cell dry weight $80.13 \mathrm{~g} / \mathrm{L}$ and $13.1 \mathrm{~g} / \mathrm{L}$ Human like Collagen (HLC) were acquired in the lab-scale (6 lit) while on the pilot-scale (15.4 lit) $59.7 \mathrm{~g} / \mathrm{L} \mathrm{CDW}$ and $6.25 \mathrm{~g} / \mathrm{L}$ HLC were obtained by retaining of DO at the same value (Ma et al, 2014). It is found that final cell density and amount of recombinant protein have been decreased significantly only with threefold increasing working volume of bioreactor.

\section{CONCLUSIONS}

Results of this study showed that simultaneously maintaining geometrical analogy and DO in appropriate limit, and using a combined substrate feeding strategy consisting of exponential feeding and utmost specific growth rate can guarantee the success of fed-batch scale-up of rh-GCSF production. The high amount of overall productivity of recombinant protein production during scale-up may be because of the high plasmid stability, low accumulation of secondary metabolites such as acetate, presence of main components of culture including carbon and nitrogen sources and oxygen in an appropriate concentration, provide appropriate physiological and metabolic conditions during fed batch culture with this feeding approach.

The amount of rh-GCSF was obtained in this research is one of the highest amount recombinant protein that has been reported in this scale up to now. On the other hand, due to the scale-up was done for recombinant $E$. coli fed-batch fermentation with maximum attainable specific growth rate that accompanied with more severe stress respect to other fed-batch processes methods that have been reported, we anticipate the strategy simultaneous maintaining geometrical analogy and DO in appropriate limit can be applied for scale-up other recombinant $E$. coli fed-batch fermentation successfully.

\section{ACKNOWLEDGEMENT}

Financial support and sponsorship: The present work was supported by grant BE20 by Department of Biological Science and Technology of Malek Ashtar University of Technology.

Conflict of Interests: There are no conflicts of interest.

\section{REFERENCES}

Abolghasemi Dehaghani S, Babaeipour V, Mofid MR, Divsalar A, Faraji F, An efficient purification method for high recovery of Recombinant Human Granulocyte Colony Stimulating Factor from recombinant E. coli, Int J Environ Sci Technol Dev. 2010, 1(2): 111-114

Akesson M, Hagander P, Axelsson JP, Avoiding acetate accumulation in Escherichia coli cultures using feedback control of glucose feeding. Biotechnol Bioeng. 2001, 73, 223-230.

Babaeipour V, Haji Abbas MP, Sahebnazar Z, Alizadeh R, Enhancement of human granulocyte-colony stimulating factor production in recombinant E. coli using batch cultivation. Bioprocess Biosyst Eng. 2010, 33, 591-598.

Babaeipour V, Khanchezar S, Mofid MR, Haji Abbas MP, Efficient Process Development of Recombinant Human Granulocyte Colony-Stimulating Factor (rh-GCSF) Production in Escherichia coli. Iran Biomed. J. 2015, 19,102-110.

Babaeipour V, Shojaosadati SA, Robatjazi SM, Khalilzadeh R, Maghsoudi N, Over-production of human interferon- $\gamma$ by HCDC of recombinant Escherichia coli. Process Biochem. 2007, 42, 112-117.

Babaeipour V, Shojaosadati SA, Maghsoudi N, Maximizing Production of Human Interferon- $\gamma$ in HCDC of Recombinant E. coli, Iran J Pharm Res. 2013, 12(3):563-72.

Bradford MM, A rapid and sensitive method for the quantitation of microgram quantities of protein utilizing the principle protein dyebinding. Anal Biochem. 1976, 72:248-254.

Burnette WN, Western Blotting': electrophoretic transfer of proteins from sodium dodecyl sulfate-polyacrylamide gels to unmodified nitrocellulose and radiographic detection with antibody and radioiodinated protein A, Anal Biochem. 1981, 112:195-203

Bylund, F.; Collet, E.; Enfors, S.O.; Larsson, G. Substrate gradient formation in the large-scale bioreactor lowers cell yield and increases by-product formation. Bioprocess Eng. 1998,18, 171-180. 
Choi JH, Keum KC, Lee SY, Production of recombinant proteins by high cell density culture of Escherichia coli. Chem. Eng. Sci. 2006. 61, 876-885.

Chung YC, Chien, II, Chang DM, Multiple-model control strategy for a fed-batch high cell-density culture processing. J. Process. Control. 2006, 16, 9-26.

Ge B, Tang Z, Zhao F, Ren Y, Yang Y, Qin S, Scale-up of fermentation and purification of recombinant allophycocyanin overexpressed in Escherichia coli. Process Biochem. 2005, 40, 3190-3195.

Hewitt CJ, Caron N, Axelsson B, McFarlane CM, Nienow AW, Studies related to the scale-up of high cell density E. coli fed-batch fermentations using multiparameter flow cytometry: Effect of a changing microenvironment with respect to glucose and dissolved oxygen concentration. Biotechnol Bioeng. 2000,70, 381-390.

Junker BH, 2004. Scale-up methodologies for Escherichia coli and yeast fermentation processes. J. Biosci. Bioeng. 97:347-364.

Jafari S, Babaeipour V, Eslampanah Seyedi E, Rahaie M, Mofid MR, Haddad L, MM Namvaran, Fallah J, Recombinant production of mecasermin in E. coli expression system. Res Pharm Sci. 2014, 9, 453461.

Lee SY, High cell-density culture of Escherichia coli. Trends Biotechnol. 1996, 14,98-105.

Li B, Sha M, Scale-Up of Escherichia coli Fermentation from Small Scale to Pilot Scale Using Eppendorf Fermentation Systems, Eppendorf Application note, 2016, No. 306, August, 1-7.

Ma X X, Fan D D, Zhu C H, Shang Z F, Mi Y, New correlation of volumetric oxygen mass transfer coefficient scale-up in aerobic fermentation of recombination E. coli, J Chem Pharm Res, 2014, 6(7):1810-1817

Matsui T, Shinzato N, Yokota H, Takahashi J, Sato S, High cell density cultivation of recombinant $E$. coli with a pressurized culture. Process Biochem. 2006, 41, 920-924.

Phue JN, Shiloach J, Impact of dissolved oxygen concentration on acetate accumulation and physiology of E. coli BL21, evaluating transcription levels of key genes at different dissolved oxygen conditions. Metab. Eng. 2005,7, 353-363.

Rao DVK, Ramu CT, Rao JV, Narasu ML, Rao AKSB, Impact of dissolved oxygen concentration on some key parameters and production of rhG-CSF in batch fermentation. J. Ind. Microbiol. Biotechnol. 2008,35,991-1000.
Shiloach J, Fass R, Growing E. coli to high cell density-A historical perspective on method development. Biotechnol. Adv. 2005, 23, 345-357.

Thiry M, Cingolani D, Optimizing scale-up fermentation processes. Trends Biotechnol. 2002, 20, 103-105.

Trinh LB, JN Phue, J Shiloach, Effect of methanol feeding strategies on production and yield of recombinant mouse endostatin from Pichia pastoris. Biotechnol Bioeng. 2003, 82, 438-444.

Tripathi NK, High yield production of heterologous proteins with Escherichia coli. Def. Sci. J. 2009, 59, 137-146.

Valentinotti S, Srinivasan B, Holmberg U, Bonvin D, Cannizzaro C, Rhiel M, Von Stockar U, Optimal operation of fed-batch fermentations via adaptive control of overflow metabolite. Control Eng Pract. 2003, 11, 665-674.

Varedi Koolaee SM, Shojaosadati SA, Babaeipour V, Ghaemi $\mathrm{N}$, Physiological and Morphological Changes of Recombinant E. coli During Over-Expression of Human Interferon-g in HCDC, Iran $J$ Biotechnol, 2006, 4 (4), 230-238

Weber K, Pringle JR, Osborn M, Measurement of molecular weights by electrophoresis on SDS-acrylamide gel. Enzymology , 1972, 26:3-27.

How to cite this article:

Babaeipour V, Mofid MR, Khanchezar S, Faraji F, Abolghasemi S. Bench-scale Overproduction and Purification of recombinant GCSF in Escherichia coli fed-batch process. J App Pharm Sci, 2017; 7 (08): 149-155. 